\title{
Practicing and Preaching Quakerism: Creating a Religion of Peace on a Slavery-Era Plantation
}

\section{John M. Chenoweth}

\begin{abstract}
A meeting of the Religious Society of Friends ("Quakers") formed in the British Virgin Islands in the 1740s offers a window onto broader practices of religion making. Equality, simplicity, and peace form a basis for Quaker thought, but in the BVI these ideals intersected with the realities of Caribbean life and the central fact that members also held enslaved Africans. What members did to create Quakerism varied for this group, yet it was nonetheless understood to be a part of the broader community of "Friends." Practice perspectives are employed here to gain access to seemingly ephemeral religion through the concrete objects of archaeology but also as a means of reconciling variation in practice with the idea of a coherent religion. Here religious identity was negotiated through practices on multiple scales, creating unity via larger-scope practices of writing and reading while the most frequent identifications were local and variable. Written works are often seen to encode a static, "real" version of religion against which actions can be measured, but I will argue that religion is better seen in practice, and here Quakerism was created at least as much in the variable minutia of individual performance as in widely shared documents. [religion, historical archaeology, practice theory, Caribbean, Quakerism]
\end{abstract}

RESUMEN Una reunión de la Sociedad Religiosa de Amigos (Cuáqueros) formada en las Islas Vírgenes Británicas (IVB) en los años 1740s ofrece una ventana hacia prácticas más amplias de formación de religión. Igualdad, simplicidad, y paz forman una base para el pensamiento cuáquero, pero en las IVB estos ideales intersectaron con las realidades de la vida caribeña y el hecho central que también miembros retuvieron africanos esclavizados. Lo que los miembros hicieron para crear cuaquerismo fue diferente para este grupo, sin embargo, aún así, fue entendido como parte de una comunidad de "Amigos" más amplia. Perspectivas de la práctica son empleadas aquí para ganar acceso a una religión aparentemente efímera a través de objetos concretos de arqueología, pero también como un medio de reconciliar la variación en práctica con la ideas de una religión coherente. Aquí la identidad religiosa fue negociada a través de prácticas en escalas múltiples, creando unidad a través de prácticas de escritura y lectura de mayor alcance mientras las identificaciones más frecuentes fueron locales y variables. Trabajos escritos a menudo se ven como codificando una versión estática, "real" de la religión en contra de la cual acciones pueden ser medidas, pero argumentaré que la religión es mejor vista en práctica, y aquí cuaquerismo fue creado al menos tanto en minucias variables de desempeños individuales como en documentos ampliamente compartidos. [religión, arqueología histórica, teoría de la práctica, Caribeña, Cuaquerismo]

E merging with a dedication to equality and pacifism in the 1650s in rural England, Quakerism seems more than out of place on a poor slave plantation in the 18th- century Caribbean. Yet the white, slaveholding population of thirty or forty such plantations in the British Virgin Islands (BVI) came together in the 1740 s to form a meeting of the 
Religious Society of Friends (the formal name of Quakerism) and established close ties to English Friends. Drawing on archaeological work on one of these plantations, located on the island of Little Jost van Dyke in the British Virgin Islands, my research shows how some of the practices of this group differed in meaningful ways from Quakers elsewhere.

Living in a local context very different from that in which Quakerism originated, these women and men felt themselves to be full members of their religious society, even though they enacted the group's ideals creatively. Through landscape and foodways, for instance, they produced expressions of Quaker ideas different from and perhaps unrecognizable to their fellows in London or Philadelphia. They used these to build a community: a religious identity group. This project seeks to understand the relationship of these variable, local interpretations with those of the broader Quaker community around the Atlantic world. I will argue that lo$\mathrm{cal}$ interpretations are a vital part of religion and religious identity.

Often seen as disconnected from the material, religion has been called the most difficult part of social life to access archaeologically (Hawkes 1954). An archaeology of religion can benefit from practice-centered theoretical perspectives because they ground seemingly ephemeral abstractions like religion and religious identity in the recoverable minutia of daily life. Under practice, rather than reflecting religion, small-scale actions actively define the sacred and secular, recursively creating the religious group. In addition, theories of practice help us approach an understanding of religion that is not limited to (but does not reject) static, written representations. In the Caribbean case study presented here, site layout and faunal remains will be shown to be a part of how BVI Quakerism was shaped in a way consonant with Caribbean racial and class divisions, adapting Quakerism to a slavery-based society. None of these adaptations are reflected in the written record, but I argue that they were no less a part of Quakerism, worthy of recovery and study. This suggests that archaeology is in fact a vital part of studying religious groups because the archaeologically recoverable materials tied up in nontextual negotiations or "ritualizations" such as these are our only window onto some of the actions that give shape to religion and the religious identity group.

\section{IDENTITY, PRACTICE THEORY, AND THE ARCHAEOLOGY OF RELIGION}

Religion is difficult to define. In place of true definitions, many have offered lists of the practices (often "rituals") in which members engage as a partial definition of religious groups. Quakerism is particularly subject to this because it seems to entail so many distinctive practices. Perhaps the most cited example is John Gough, who wrote, for instance, that "uncovering the head, bowing, and bending the knee, being marks of divine worship, [Quakers] think ... are marks of reverence not due from man to his fellow-creature" (1789:76-77). Such descriptions of religion - checklists of habits and exegesis explaining them - are offered to explain what it is to be a member of a religious group: Quakers are the people who refuse to bow, who say "thee" instead of "you," who wear broad-brimmed hats, and so forth.

Such lists have been used in archaeological studies of religion as well because they offer concrete, material handles by which to hold the ephemeral ideas of the "numinous." But what of a person who follows these procedures for different reasons or is not acknowledged as a member by others? Can those who act differently still be seen as members? How differently can they act before they are no longer seen as members? Such lists seem an inadequate account of what membership in a religion entails, and they are ill-equipped to deal with diversity in religious practice: for example, changes over time or members who do not follow such dicta precisely. In addition, tracing archaeological observations to single causes, such as the presence of a certain religion, is difficult in part because most material culture cannot be said to have a single cause. It is problematic to ask, for instance, if a site reflects more Quaker "simplicity" or economic poverty. Such questions imply a checklist conception of religion, but for some, their economic limitations may not have made their simple material culture any less about religion.

In this study, I employ two tactics to both engage with religion through the tangible material of archaeology and to account for variability. The first is to focus on how religion functions as a group of people, socially created and defined: a social identity. "Identity" is taken here to be the product of a never-completed process wherein individuals come together in continually creating and re-creating a group. Identity studies in archaeology are not new, and in the past decade, several have convincingly argued that identity is multiple, overlapping, and a continuing process (see Chenoweth 2009). In particular, engagement with single facets of identity in isolation has been argued to be overly simplistic: the identity "woman" cannot encapsulate the experiences of, say, both a black and a white woman in a slave society. With this present study, I hope to reinforce this conclusion, tracing the connections between religious identity making, race, class aspirations, and geography.

Increasingly recognizing the complexity of social identity, archaeologists have turned to the second tactic I employ in this article: practice perspectives. These offer two advantages: a way of seeing the material aspects of religion as integral to religion (not simply reflective of inward states or belief) and an accommodation of variation observed in this material.

\section{Material Religion and Texts}

Practice perspectives emerged as a response to "hypercoherent" models, which tended to see people as being very largely constrained by either "the hidden hand of structure or the juggernaut of capitalism" (Ortner 1984:144). Instead, practice models saw structure, or "the system," as setting conditions for, but not determining, individuals' actions. Moreover, individuals and their actions are seen as the source of these structures, "the building-blocks of social 
phenomena" (Schatzki 2001:1). With practice understood broadly, following Sherry Ortner (1984:149), as "anything people do," the most minute actions - cooking a meal, sweeping a floor, repairing a structure — can be argued to be important parts of the creation and re-creation of larger-scale social phenomena, including religion.

Of particular importance for archaeologists is that, in practice approaches, social life is created in "materially mediated nexuses of activity" (Schatzki 2001:11, emphasis in original), making archaeologically recoverable material central. In fact, Rosemary Joyce argues not only that archaeology needs practice theory but also that practice theory needs archaeology for its "understanding of the repetition of practices over time, and their mediation through the material forms in which human action is embedded" (Joyce 2012:181). Several archaeologists have applied these approaches to religion (Bradley 2003; Hodge 2005; Stahl 2008; Wilkie 2000), and these and others (e.g., Keane 2008) have forcefully argued that religion has a material aspect.

A full review of the archaeology of religion is beyond the scope of this article, but the use of written works deserves comment, as this focus on materially mediated practice leaves their role in question. Written religious exegesis has played a major role in the analysis of religion, in part because religion is often seen as being about the kinds of thoughts expressed in writing. Texts have also offered tempting explanations in historical archaeologists' efforts to understand religion, sometimes problematically providing a "real" version of religion against which actions can be tested. A "gotcha" archaeology (Chenoweth 2012) concludes that members of a religion did or did not live as they were "supposed to" based on written exegesis, but little is added to our understanding through this comparison.

More insightful and developed analyses employing texts, material, and religion include Leland Ferguson's (2011) analysis of how burial ground and town layouts reflect Moravian values in Salem, North Carolina. The rise of racism among Moravians is seen as "at odds with [their] values" and "contradictory with their ideals" (Ferguson 2011:16, 195). Here I take ideology less as a static benchmark against which to measure changing practice, and I focus on action over written texts: if religion takes shape through action, changing practice means that what it is to be a member of a religion is itself changing. As a result, the goal here is the interaction of practice and ideals, not just how practices reflect — or fail to reflect-ideals, and thus this article aims to be an extension of Ferguson's interesting discussion. Written works are vital evidence in historical archaeology, but here they will be seen as practices themselves and compared to more frequent, nontextual, local acts of religious practice.

\section{Variation}

Another advantage of practice approaches is their ability to help break down "unnecessary rigidity in material categories" (Silliman 2009:213) because, rather than static checklists of traditions, "all people [can be seen to] enact, embody, or re-present traditions in ways that continuously alter those traditions" (Pauketat 2001:79). Pierre Bourdieu (1977:10) critiqued earlier models of social structure that focused on "norms and rules," akin to these checklists. In the present study, the variation detected archaeologically in the BVI Quaker community would clash with this view of religion. Religious conversion is not usually seen to be "creative" as much as "re-creative"; that is, converts do not intend to introduce variability into their new religion but to reproduce it. A checklist approach would lead us to expect a similar "Quakerism" in the BVI and elsewhere. But even when people act to reproduce structure, their actions can clash with the received categories that motivate them, altering the system itself (Sahlins 1981:67). Conversion can be cast as submission or blind following, but Michel de Certeau (1984) reminds us that actions that may have been seen as prescribed reproduction can take on new meanings and come to operate on the system rather than solely within it. Thus, even precisely replicated Quaker practice, for instance, cannot be said to purely reproduce Quakerism. Variation in practice is an inevitable part of social life, yet groups are created and held together through these variable actions.

The context of action is one source of this variation. Through what actors know or believe about their circumstances ("knowledgeability") and the "monitored character of the ongoing flow of social life" ("reflexivity"), agents learn about their world, including the actions of others, and this informs further action (Giddens 1984:3, 375). In saying this, Anthony Giddens makes social life inevitably contextual and historical. Actions, once taken, become immediately a part of the ongoing flow of life and are monitored by others, informing the knowledgeability of agents and their next set of actions (although not without unintended consequences).

This emphasis on the local and variable does not, however, make the study of the social reproduction of religion an idiosyncratic one. Religions are not individual; instead, as approached here, they are coherent groups of peopleidentities. The work of Catherine Bell (1992) offers a way of keeping focus on the local while also recognizing broader connections. Bell's approach to ritual - a concept fundamentally related to religion, although different - is to focus on action, discussing not "ritual" but "ritualization," the production of an unequal difference between sacred and secular ways of acting. For her, it is not the actions so differentiated - what have been called "the rituals" - that should be studied but, rather, "how such activities constitute themselves as different," as these differences are "strategic" and "value-laden" for members of a group (Bell 1992:90). The focus becomes not a particular action but a quality of being "ritualized" that some actions possess.

Mark Aldenderfer (2012:24) recently suggested that Bell's ideas about ritual have resulted in an exclusion of religion from archaeological work. Without taking issue with Aldenderfer's goal of studying “what religion does," I suggest that by focusing on distinctions and how they are value laden, Bell's theories on ritual do offer a possibility of approaching 
larger religious structures. Here, a religion can be thought of as an identity, a group of people engaged in drawing privileged distinctions in ways of acting (ritualization) based on a particular set of values or in attempting to reproduce a certain set of structures. A religion, as a social group, is created from a particular approach to ritualization.

It is important to note that Bell's theory does not hold that the resulting actions must be mechanical or precisely repeated, factors usually key to the definitions of rituals: "formality, fixity and repetition are not intrinsic qualities of ritual so much as they are a frequent, but not universal strategy for producing ritualized acts" (Bell 1992:92). This ritualization is not mechanical but, rather, actively created by agentive participants. Religion is performed, in Judith Butler's sense: an active (though not always free) strategy of replication on the part of agents. Butler writes that "being a man" and "being a woman" are "internally unstable affairs" (Butler 1993:126). In the same sense, so is being a Quaker.

Bell argues that the ways actions are ritualized - that is, differentiated - are relational and contextual. She writes, "basic to ritualization is the inherent significance it derives from its interplay and contrast with other practices" (Bell 1992:90). In this interplay and marking of contrast, the "sacred" is created through practice "by virtue of its sheer differentiation from the profane" (Bell 1992:91). Her point is that religious typologies are impossible, but her argument also serves to establish ritualization as a fundamentally local phenomenon. If this is so, the context in which daily life occurs must have a role in shaping the social group built from these practices: economic necessities, social aspirations, and environmental and social dangers all alter how people get on in the world and thus their ritualizations and the group these create.

The creation of religion, then, entails actions in daily life whose roles and meanings (as sacred or secular) are negotiated along with the larger structure of the religion, recursively. This negotiation creates the group of peoplethe religious identity group. The importance of daily habits (eating, cleaning, dressing, etc.) gives a central role to elements of material culture that are implicated in those habits and recoverable archaeologically. Following Marshall Sahlins (1981), attempts at reproduction in these practices can lead to change. Following de Certeau, what is apparently successful reproduction can actually be creative. Giddens and Bell force us to understand the historically situated minutia of local attempts to re-create structure - different efforts to practice religion the "right" way.

Better understanding of a religious community like the BVI Quakers does not come from a listing of their practices but from a study of how local religious practice "functions to produce that which it declares" (Butler 1993:107), of how the sacred and profane are marked and made through the production of unequal differences between ways of acting, and of how these differences come about in negotiation with other facets of identification such as race and class. I now turn to the British Virgin Islands Quakers to suggest some answers to these points for one particular context.

\section{CARIBBEAN QUAKERISM AND ITS WRITTEN RECORD}

The Religious Society of Friends was born about 1650 out of the economic, political, and religious turmoil of the English Civil War. Quaker thought centers on the ideal of the "Inner Light" through which one can have unmediated contact with the divine. This gave rise to a rejection of sanctified places and people (churches and ministers); to "simplicity" in material possessions; and to "equality" between people and thus pacifism, leading eventually to involvement with the abolition movement in the 19th century. In the 1670s, Quakerism spread to most parts of the British colonial world, including the Caribbean. Historians have described Quakerism's rise as a messianic movement, its contraction into "quietude," and its schism and reunion, but archaeological engagements with Quakerism are nascent, and these suggest significant variability in patterns of Quaker practice (Chenoweth in press).

Though flourishing in the 1690s, Caribbean Quakerism largely disappeared by the early decades of the 18 th century. Few records of these groups remain, although those that do have received detailed attention (Durham 1972; Gragg 2009). By the time a small community of Quakers formed on Tortola in the British Virgin Islands (Figure 1) in 1740, they were almost alone in the Caribbean. All of the members of this group, which existed formally only until 1762, were already resident in the BVI before their conversion. Most were slaveholders.

The BVI is a collection of about 40 steep and dry islands, historically marginal to the Caribbean economy and society. Settled late in the colonial process, they were little contested by the European powers. Early settlement was haphazard and informal, with recorded beginnings in the 1670s and arriving at a stable population only in the early 1700 s. There was limited government (a legislature was granted only in 1773) and an Anglican minister was not appointed until 1745, possibly in response to the formation of the Quaker meeting in 1740, although overall resistance to and persecution of BVI Quakers was muted compared to their earlier receptions (Durham 1972; Jenkins 1923). The islands enjoyed brief periods of prosperity when cotton and sugar prices were high but never developed the wealth of larger plantation economies. After slavery, the islands' population became almost entirely black smallholders (O’Neal 2012) who had limited interference from their colonial government but who were economically restricted to subsistence and labor-based emigration.

Tourism and financial services have changed the economic fortunes of the BVI in recent decades, but there is still little historic or archaeological work available as a starting point from which to consider BVI Quakers (exceptions include Dookhan 1975; Harrigan and Varlack 1975; 


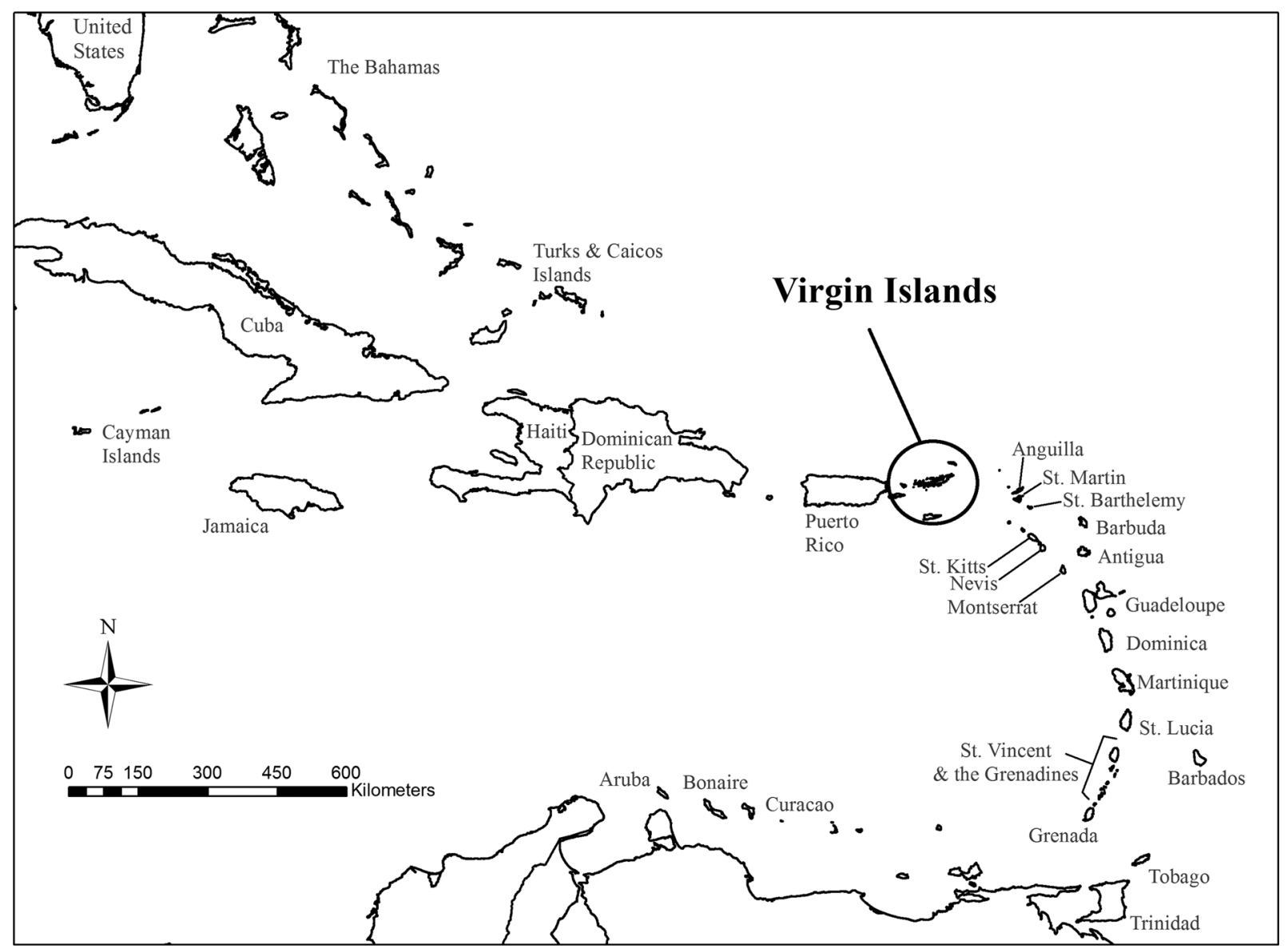

FIGURE 1. The Caribbean with the British Virgin Islands indicated. (Map created by the author, based on data from the Pacific Disaster Center [ghin.pdc.org])

and Jenkins 1923). The published archaeological work in the BVI is almost entirely pre-Columbian in focus (for a summary, see Chenoweth 2011:67-68). The Guana Island plantations of the Lake and Park families, also members of the BVI Quaker community, have been the subject of a series of studies out of the College of William and Mary, but with one exception (Mahoney et al. 2005) these have yet to be published. A recent survey of the historical defenses of the BVI has been conducted (Kent 2009). No other Quakerfocused archaeological projects in the Caribbean are available for comparison.

The presence of "pacifist" Quakers in the slaveryera Caribbean has attracted the attention of other scholars. Barbados, once called by Quakers the "nursery of Truth," had as many as six meetinghouses (Durham 1972) and a series of 17th-century laws suppressing Quakerism (Dunn 1972:103-106). Barbadian Quakers clashed with others on the island mainly over pacifism, oath taking, and tithes (Dailey 1991; Gragg 2009:39). A few Quakers advocated conversion of the enslaved, although these were probably isolated cases (Benjamin Lay was actually expelled from Quakerism for this suggestion). These must be compared to the masses of Friends who owned Africans both in the Caribbean and mainland North America (McDaniel and Julye 2009; Soderlund 1985). In the main, American "Quakers ... embraced slavery as a natural part of the social system" (Durham 1972:82), and acceptance of nonwhites as members was extremely rare and usually informal until modern times (Cadbury 1936).

While not seen as equal to whites, nor as full members of the Society of Friends, there was nonetheless a paternalistic concern for the actions and souls of Africans held by Quakers. Quaker writings contain few references to slavery before or during the period of the BVI meeting, but those that can be found are clear that enslaved people should be treated as part of the Quaker community - albeit controlled and cared for much like children (Soderlund 1985:181). George Fox, one of the movement's principal founders, asked that Quaker slaveholders care for those they held and teach them "Christian ways" (Durham 1972:18), and he considered enslaved people to be part of their owners' families (Fox 1701). He suggested that owners should be mindful of "training up their negroes in the fear of God" (Fox 1952:598). Quakers were to control and restrict the actions of those they held to keep the enslaved people from sin, the inevitable result of what William Edmundson, the principal advocate of proselytizing to enslaved Africans, called their "filthy liberty" when it was not properly controlled (Gragg 2009:138). 

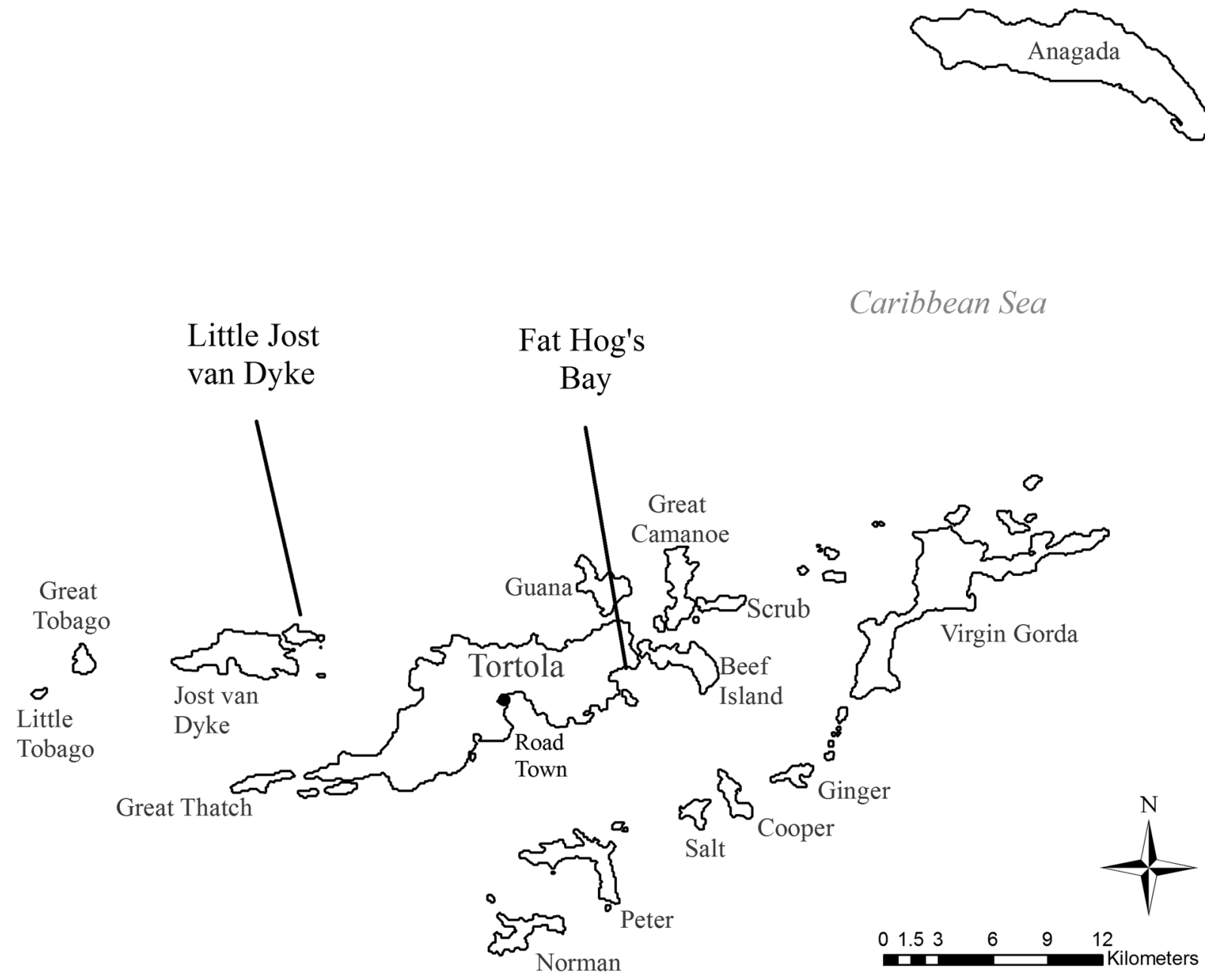

FIGURE 2. The British Virgin Islands with Little Jost van Dyke and Fat Hog's Bay. (Map created by the author, based on data from the Pacific Disaster Center [ghin.pdc.org])

Yet this writing emanated mainly from English Friends, not local Caribbean converts like the BVI islanders, and its reception in terms of religious practice in the Caribbean is a matter for discussion. Many historians have assumed that Quakers were more "kind" slaveholders than others, although little evidence has been offered for this (in truth, this is more of an archaeological question). What is clear from the early England-based written record is that one version of Quakerism held that members could hold enslaved people but were responsible for their spiritual welfare. Thus, slaveholding Quakers might be expected to observe those they held in bondage more closely than other slaveholders, guarding against subversion not just of their economic goals (escape, inefficiency, "laziness") but of their religious ones (drunkenness, swearing, dishonesty, promiscuity, violence) as well.

\section{THE LETTSOM SITE ON LITTLE JOST VAN DYKE}

Archaeological work on the site of one plantation owned and occupied by members of the BVI Quaker community, the Lettsoms, offers a window into daily practice as they nego- tiated demands that were often at odds: Quaker ideology, slaveholding practicalities, and the economics and dangers of life in the marginal Caribbean. The material recovered in archaeological work speaks to the patterns of life on this site and the decisions made by its occupants. Practice theory directs our attention to these small-scale actions and interactions of the residents on such sites, as these are the building blocks of religious identity among other social phenomena. As discussed at the outset, the material culture of this site will not be read as "reflecting" or being "caused by" Quakerism in a simplistic way. Instead, the findings will be interpreted as being shaped by the occupants' desires to live in a Quakerly way and suggesting to us what exactly a "Quakerly way" meant to them, as it is in these actions and relations that what it means to be a Quaker takes shape. Quakerism itself is built from these actions of attested members.

This project consisted of historical and archival research and three seasons of survey, mapping, and excavation on Little Jost van Dyke Island, and preliminary excavation was also conducted on the remains of the community's meetinghouse, located at Fat Hog's Bay, on Tortola (Figure 2). 


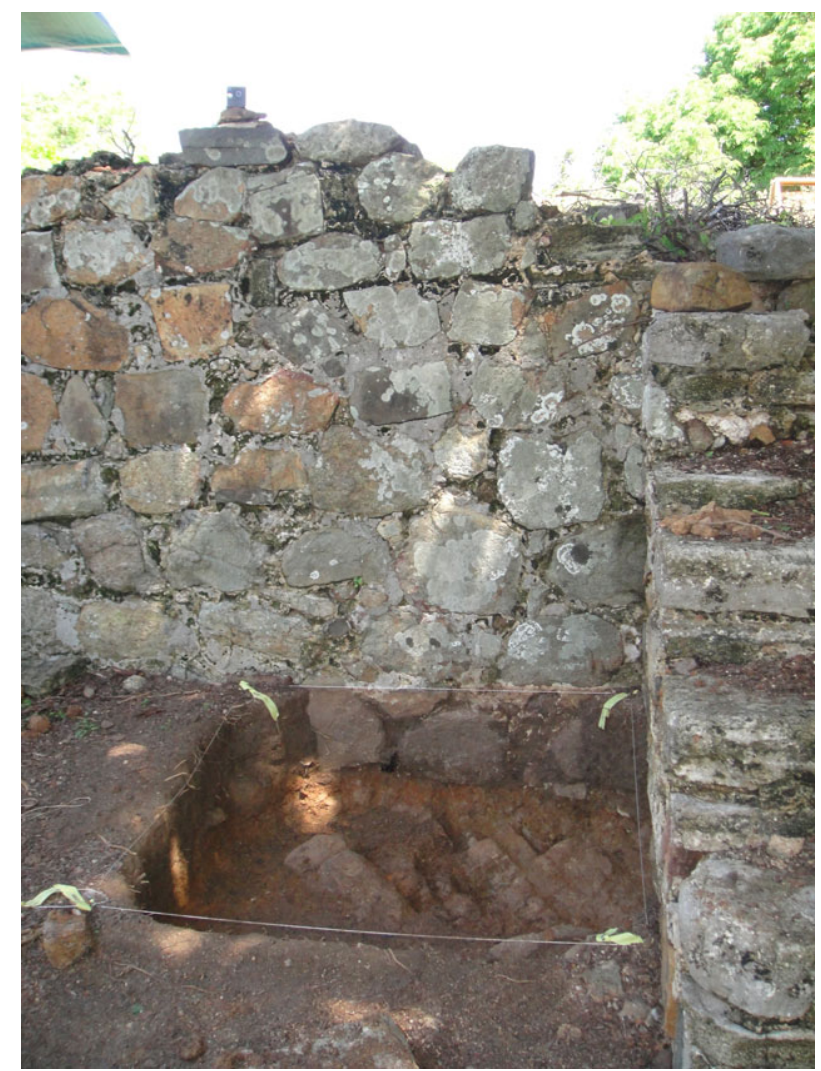

FIGURE 3. Foundation of the Lettsoms' house and excavation unit. (Photo by the author)

The enslaved population of "Little Jost" deserves its own discussion, which is in preparation as a separate article.

From the 1720 s to the 1780 s, Little Jost was home to Mary and Edward Lettsom; at least two sons, Edward and John (twins b. 1744); and an uncertain number of enslaved people of African descent. The Lettsoms were probably poorer than many planters, even in the marginal BVI (Chenoweth 2011:274-276, 293-295). The small but well-built, single-faced stone foundations of the Lettsoms' house mostly survive to their original height, up to a meter and a half at points because of the slope (Figure 3). Wattle-impressed mortar fragments indicate the construction of rest of the building, and the many surface artifacts have been shown to cluster near their points of discard (Chenoweth 2011:165-166). Artifacts were almost entirely restricted to 18 th-century materials. Other surface-visible remains include at least five fieldstone graves (Figure 4), a collapsed oven, a mortar-floored storage structure, and several areas of low field terraces, sized for cotton plants. John, son of Mary and Edward, wrote much later in life that this was his parents' main crop (Lettsom 2003:13).

This same son set the number of enslaved people on the island at about 50, but this number seems doubtful (Chenoweth 2011:274-276), and a 1765 account shows what looks like a single extended family: an older couple (Rosett and Cudjoe), a younger couple (Cassia and Bentorah), and four children (Cutto, Myal, Toney, and

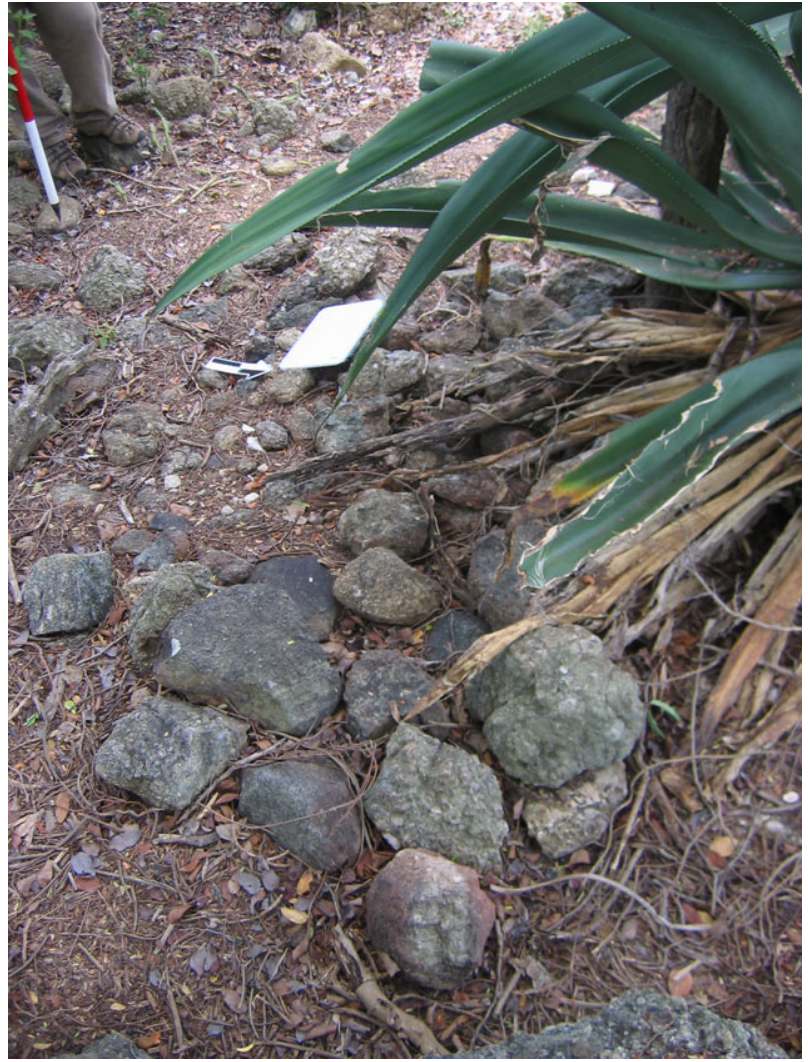

FIGURE 4. Fieldstone grave on Little Jost van Dyke. (Photo by the author)

Nanny), with two single men (Tom and Damon). These residents lived in an area termed "Area E" (Figure 5), a level but stony patch identified through a dense concentration of surface artifacts and on the basis of a vague historical description (Lettsom 2003:13). A few stone alignments, possibly foundations, and a few fragments of wattle-and-mortar were found here, but efforts to locate architectural remains were largely unsuccessful. Soils here are sandy, active, and shallow, and they do not preserve postmolds or living floors. Therefore, data on the enslaved population comes from a subsurface survey grid of 50-centimeter units.

\section{LOCAL VARIATIONS AND TRANSATLANTIC CONNECTIONS Plantation Landscapes}

The discussion of the written record of Quakerism and slavery above noted a concern for the spiritual welfare - as those in power saw it - of the enslaved Africans, and, thus, a responsibility to keep them from committing "sinful" actions. Given this, we might expect increased efforts at control on the site. Under practice, the small-scale interactions of the residents on such sites are structured by and structure the landscape in which they are set - the layout of the site and distribution of various artifacts across it compared to other sites. Many factors were at play in the layout of a plantation, including the crops grown, chronology, and even wind direction, but major foci in plantation archaeology include power, control, and surveillance of the enslaved laborers. 


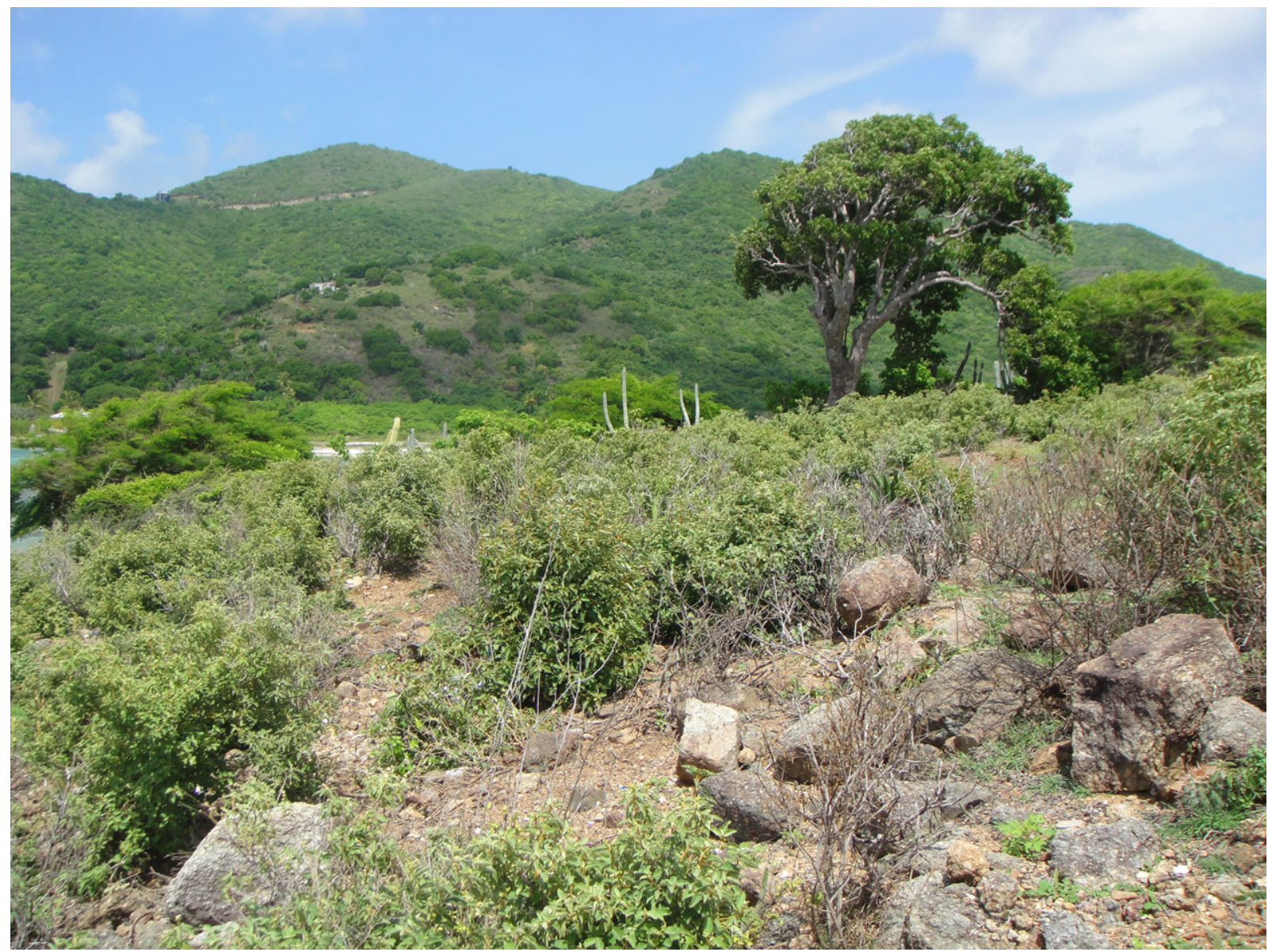

FIGURE 5. Area E, identified as the village of the enslaved Africans through surface deposits and documents. (Photo by the author)

These relations of power are seen by many archaeologists as being worked out in daily practice, in part through the structure of plantation sites.

Moment-to-moment surveillance or its threat was largely economic, but it would also have been vital to enforcing "Christian ways" among the enslaved. This has Quaker precedents, as the "policing" by white members of each other's moral behavior was part of the purpose of the system of meetings. In the Caribbean, therefore, we might expect the economic system of surveillance to be repurposed and expanded to enforce Quaker morality among the enslaved people as well as to support the planters' economic goals. However, the Lettsom site does not follow this directive.

Power was negotiated in plantation landscapes both through direct control and through rhetorical structures such as panoptic surveillance. Control of the enslaved Africans, who far outnumbered free whites, was always a concern in the Caribbean and U.S. South. Quarters and yards have been sites of autonomy and resistance, and enslavers planned plantation layouts to maintain order (BattleBaptiste 2011:93, 99). Historian Stephanie Camp argues that, in the U.S. South, "slaveholders put the principles of restraint into practice in everyday life ... building 'geographies of containment'” (Camp 2004:16). Archaeologists have described a number of these strategies, including provi- sion for physical control, such as "jail-like" housing structures (Singleton 2001), especially earlier in Caribbean colonialism (Hicks 2007).

But power was also negotiated in subtler, rhetorical ways, such as differential access to goods (Hauser 2011:433) and provision for surveillance at work and in quarters. Jerome Handler and Frederick Lange concluded that there was a "general pattern" in Barbados of slave villages being close to the owner's or overseer's house or within full view of it (Handler and Lange 1978:46). This pattern is also found in Jamaica by Douglas Armstrong and Kenneth Kelly (Armstrong 1990; Armstrong and Kelly 2000:377) at Drax Hall and Seville, and by Barry Higman (1998:100) at Montpelier. This was for economic reasons, minimizing travel times, but plantation landscapes were also carefully managed to allow for oversight (Delle 1998, 1999; Higman 1998). The pattern has also been noted in French colonial sites, where desires for separation competed with a need for surveillance and control (Kelly 2008:395), and in the U.S. South (Joseph 1993:59; Orser 1988:324).

Owners of smaller plantations may have enacted surveillance by placing the residences of the enslaved people very close to their own, offering increased opportunities to oversee daily practices through which identity (primarily racial and economic but on Little Jost also religious) was 


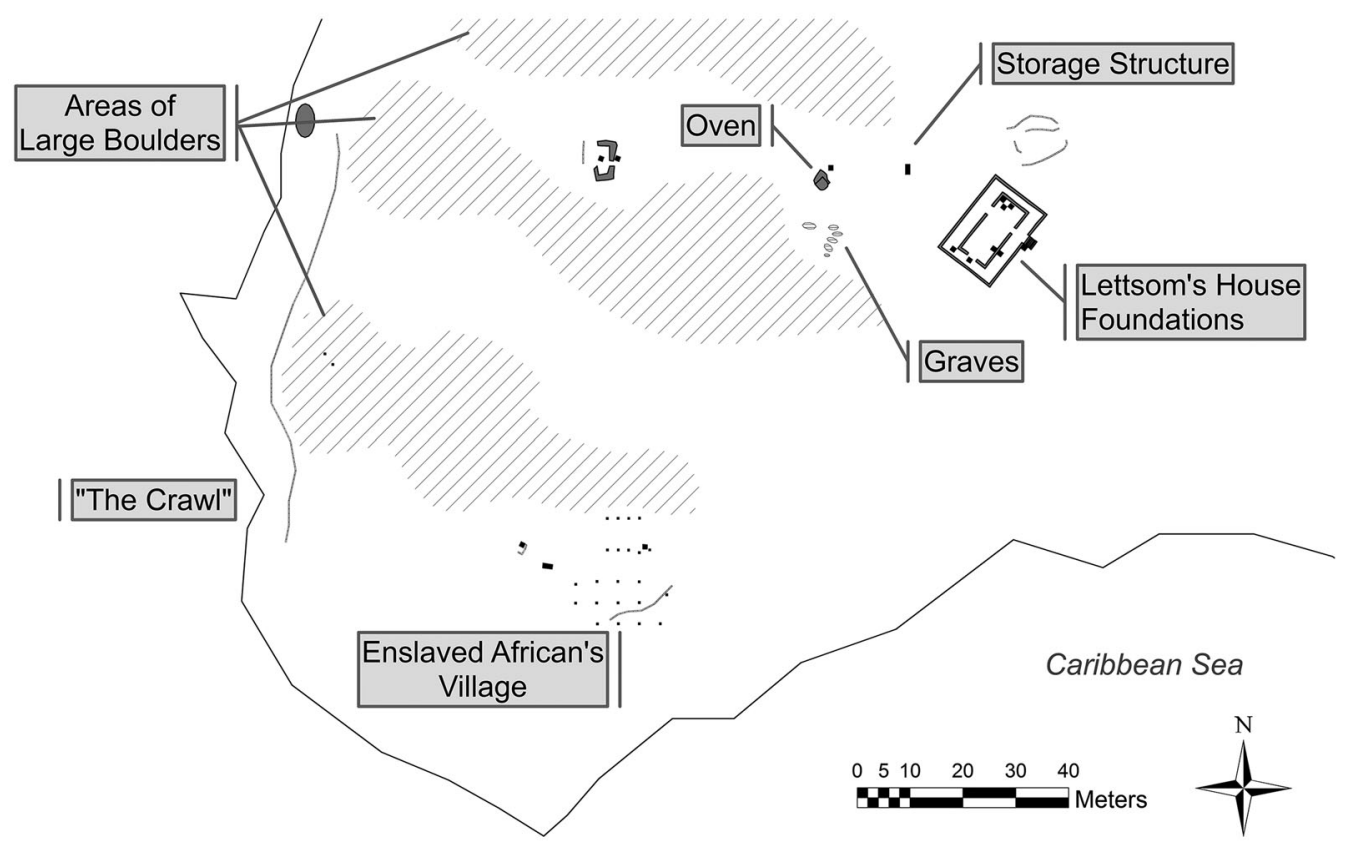

FIGURE 6. Layout of the Little Jost site. (Map by the author)

constructed. For instance, in the Bahamas it has been suggested that foodways might be a venue for control, either through centralized food distribution (reflected in the lack of storage vessels at enslaved peoples' homes) or the possibility of centralized food-preparation sites (Farnsworth 1999:125). Such tactics would have subjected even the minute actions of daily cooking and eating to control.

Whitney Battle-Baptiste (2011) issues an important reminder that whites' ideals were never fully realized and that captive Africans created their own "homespaces" through their daily practice, which prevented the plantation landscape from ever being fully in the control of the enslaver. Power was enforced through daily action but so was resistance, as enslaved Africans creatively negotiated their limitations for their own ends (Hauser 2008; Singleton 2001; Wilkie and Farnsworth 2005), and white-defined boundaries were transgressed in creative ways (Hauser 2011). However, what is notable here is the goal of the planters' actions, successful or not. Archaeological observations elsewhere have indicated efforts to control daily practice-house locations, pathways walked, and food eaten - as part of the negotiation of both economic and ideological power on many plantation sites, and while there is added incentive on Little Jost (to enforce Quaker practice), we actually see less effort to do so.

On Little Jost, neither physical controls such as walls, nor surveillance, nor forced togetherness in cooking or other daily action appears to have been built into or even possible within the plantation landscape. The homes of the free and enslaved people on the island were separated by about 100 meters and situated on different sides of a curve in the island's topography so that there was no direct line of sight, making surveillance impossible (Figure 6). Further, the enslaved people would have had easy access to a shallow area, locally termed "the Crawl," separating the island from the neighboring larger island of Jost van Dyke, allowing them to come and go from the Lettsoms' property without observation. Cooking facilities appear to be minimally shared, if at all: a now-ruined oven, which both groups may have used, is present behind the Lettsoms' home (Figure 7), but due to a line of volcanic boulders, there is no direct path from it to the homes of the enslaved Africans. They would have had to carry cooked items more than 120 meters across an area with no sign of such regular travel (surface artifacts from dishes broken in transit, for instance). Remains from the homes of the enslaved Africans, however, include bone, shell, charcoal, and a fragment of an iron cooking pot, implying separate cooking spaces.

Other factors besides control of the enslaved population certainly contributed to the layout of plantation spaces, but none appears to completely explain these observations on Little Jost. Villages may have been placed downwind of the planters to avoid their smell (Handler 2002:127), although the construction of enslaved people's houses as having a "stench" different from those of the white population may speak more to rising racial ideologies (Hicks 2007:46) than to an actual guiding principle of plantation construction. While the village on Little Jost was located to the west of the Lettsoms' house, technically downwind, the whole settlement lies in the lee of the island's 300-foot peak and the wind swirls from all directions, making wind direction an unlikely factor here. Christopher Clement (1997) suggests that planters' houses were placed to catch the breeze for ventilation, but while excavating we found it to be, on average, more sheltered and hot than the village area. 


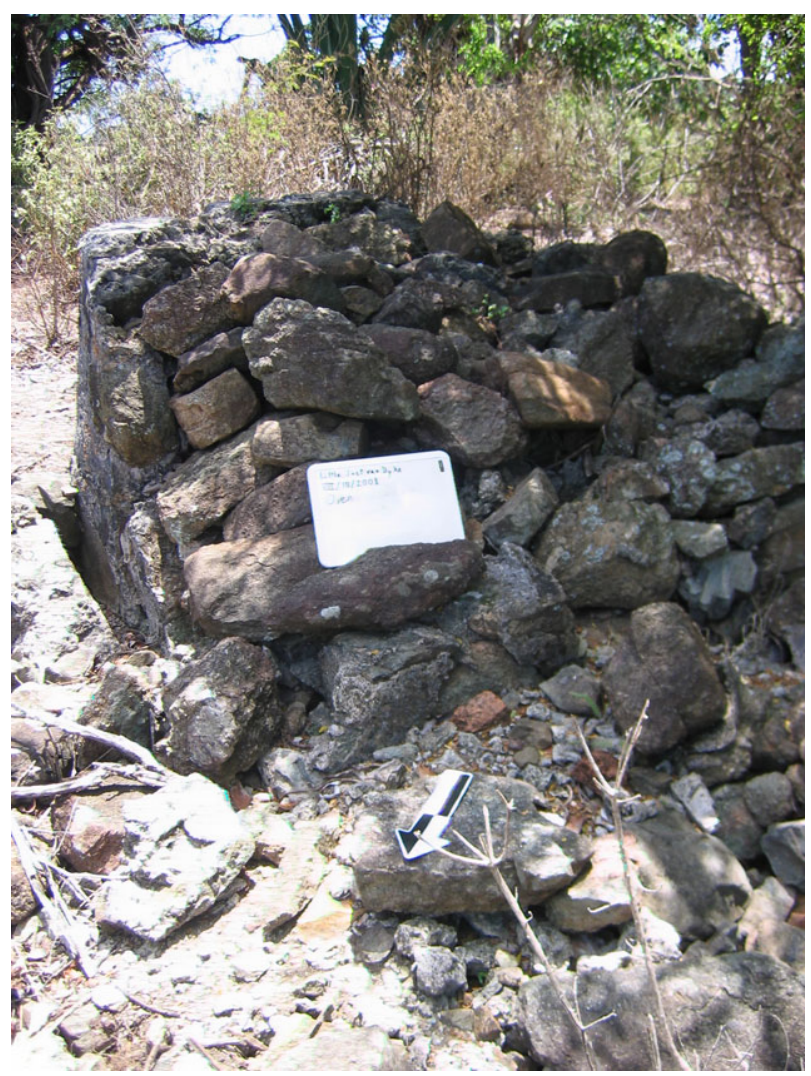

FIGURE 7. Ruins of an oven behind the Lettsoms' house. (Photo by the author)

The cultivation of different crops entailed different work regimes and also led to variation on plantations. Cotton, the cash crop grown on Little Jost, was a smaller-scale crop and entailed greater flexibility and mobility for those cultivating it. Lower oversight was also detected at the Rolle plantations on Exuma, Bahamas, also cotton plantations though somewhat larger and later than Little Jost. However, this seems at least in part to be the result of the lack of profitability of cotton by this late date and the impending end of slavery itself (Craton 1997:362-363). It should also be noted that Rolle "earned an almost legendary reputation in the Bahamas as a liberal master" (Craton 1997:229) so this lack of surveillance is unusual, even for cotton-farming sites.

Plantations using the task system, common on smaller cotton-farming sites, may have also put less emphasis on surveillance (Orser 1988:331). Though no record exists, this may have been the system employed on Little Jost. Yet this seems a partial explanation for the layout there because at least some other cotton plantations were structured to provide oversight (Otto 1984:37, 86; Young 1999) along the lines of the sugar plantations discussed above. Moreover, the slim documentary record of the BVI in this period centers on enslaved people escaping as an obstacle to economic growth (Dookhan 1975:27-28). In 1751, Lieutenant Governor Purcell complained that slaves frequently escaped to Puerto Rico (Colonial Office n.d.: CO 152/27\#Aa.39), and so it seems odd that such easy access to neighboring islands would be allowed.

In sum, while factors of size, crop, geography, and even wind may have played roles in determining the layout of the Lettsoms' plantation, none of them appear to provide a completely satisfactory explanation for the observations made archaeologically. Neither statements of power through surveillance nor direct control through togetherness could have been deployed. Yet, written Quaker directives cited above suggest a greater - not lesser — need for surveillance and control because the enslaved Africans should have been incorporated into the Quaker community (though not converted to full membership) and controlled for moral as well as economic reasons. The layout of this site may date from the early days of settlement on the island, before Quaker conversion, but Quaker priorities of inclusion and moral policing, as represented in the written record, would have argued for a reorganization of the landscape to paternalistically incorporate the Africans into daily religious practice. Archaeology has indicated that the homes of the enslaved were ephemeral, as is common in the Caribbean, and thus relocating them to the large level area behind the Lettsoms' home would have posed no great logistical challenge. That we see no evidence of this is central.

A possible explanation for this result lies in the suggestion that some common Quaker practices were directed at creating difference between Quakers and non-Quakers, creating a "hedge" around Quakerism (Frost 2003:25). I have suggested elsewhere that this difference was carefully crafted: not just separation but separation in a certain way, the rejection of overtly religious actions as separate from daily life (Chenoweth 2009). But on the Lettsom site, the daily actions through which the Lettsoms defined themselves as Quaker - created the sacred and secular through practice-were taken not amid white non-Quakers but enslaved Africans. Rather than the typical marks of difference between owners and enslaved people - attempts to control and surveil - the landscape here suggests a "hedge" separating Quaker and non-Quaker as much as free and enslaved. The material worlds of the Lettsoms and their enslaved people showed a similar division, the whites having generally older ceramics, independent of site chronology (see Chenoweth 2012). Traditional concerns of the Caribbean planter class for surveillance and control of the enslaved people and differential access to goods such as newer ceramics may have been trumped by the way Quaker identity was built in opposition to the Africans.

Probably the best comparative site for Little Jost yet published comes from Armstrong's work on the small, contemporary, but non-Quaker plantation at Windy Hill on the east end of St. John, in the then-Danish Virgin Islands (Armstrong 2003). Windy Hill is unique, but it shows one possible outcome of free and enslaved people living and working closely every day in the marginal Caribbean, with its many dangers: invasion, revolt, hurricanes, earthquakes, and isolation. Though the history of the East End is complex, 
the early occupation of Windy Hill suggests a clear distinction of free and enslaved people, with homes for each placed on adjacent but separate platforms (Armstrong 2003:132, 139, 308-309), which would make for easy surveillance of the enslaved Africans' daily lives. Cooking facilities appear to be shared, a situation suggested above as a possible strategy of control. And yet Armstrong's convincing conclusion is that, over time, distinctions between free and enslaved, white and black, blurred in the East End community including Windy Hill.

Poor whites like the Lettsoms and those living at Windy Hill lacked access to economic and social power in the community of elite whites. At Windy Hill, people adapted to the poverty and harshness of the Virgin Islands by rejecting this community outright, creating an alternative that blurred racial lines. Faced with the same dangers and problems, a similar solution of creolization was possible on Little Jost, but Quakerism offered another option: a community that offered not only religious fulfillment but access to powerful converts (the wealthiest planter in the BVI, John Pickering, was a leading convert to Quakerism) — but only if Quaker identity could be negotiated without threatening the sense of unity with other whites.

In this context, the idea of following written directions from England to incorporate the enslaved people into the Quaker community, even on an inferior level (that is, not as full members of the meeting), may well have threatened relations between Quaker and non-Quaker planters in the BVI. Rather, the "hedge" discussed above was erected through daily practice in the landscape of the island differentiating free and enslaved people at the same time as Quaker and nonQuaker. Turning to a community centering on Quakerism required reinforcing, rather than blurring, racial divisions. It has long been recognized that racialization can take place, in part, through spatial segregation (Orser 2007:111), and so the separation of free and enslaved people on Little Jost can be read as part of this process, also creating Quakerism along these racial lines.

An expected marker of Quakerism - efforts to control the moral lives of enslaved people - fails to materialize here, but this cannot be seen as a lack of Quaker influence. As this discussion and the earlier consideration of variable religious practice and texts has made clear, the ideas of BVI Quakerism were expressed and constructed amid local concerns, and we should not expect it to be performed by rote. The data here suggest a reinterpretation of what a Quaker community should look like compared to that described in the written record, as well as a restructuring of plantation space to one less focused on control and more on religious and racial distinctions. Importantly, this lack of oversight does not reflect a "kinder" slavery on Quaker plantations but, rather, a religious and racial exclusion that establishes Caribbean Quakerism in a way consonant with slavery. If Quakerism could not fit itself into the practices that created the community of hegemonic whiteness, it threatened to break that community, something few in the marginal BVI were willing to risk.

\section{Local Innovations: Simplicity and Industry}

Eating is perhaps one of the most mundane activities in which humans engage. Acquisition, preparation, and consumption of food are universally done but in highly variable ways, subject to a number of social concerns and used in the negotiation of many kinds of identities. Analysis of bone and shell remains recovered from Little Jost and the Fat Hog's Bay Meetinghouse on Tortola provide insight into interactions within the meeting group through the foods they prepared and ate. While the Lettsoms consumed a mix of domestic and wild species, there is a clear emphasis on wild, comprising 68 percent of bones identified to species. This is not surprising, given the ease of fishing off the shores of the island, which should provide ample wild fish. Shellfish remains recovered on Little Jost show that the enslaved and free occupants of the island both ate approximately the same proportion, about two-thirds, of highly desirable shellfish species still eaten today like conch (Strombus gigus) and what is locally called "whelk" (Cittarium pica) — to more "secondary" foods, suggesting no food shortages were common.

While the sample is small (NISP $=51$ ), the animal bones recovered at the meetinghouse on Tortola show a very different pattern. Of the 36 of these bones identifiable as domestic or wild, all of them are domestic. While fish bones make up the majority of remains on Little Jost, no fish remains at all were recovered from the meetinghouse. Shellfish are present, but almost all (93\%) are high-value food species. These remains are probably related to communal meals held by Quakers when they gathered for monthly meetings for business, including "dealing with" moral lapses among the membership. It is reasonable to expect that when members gathered from some distance, they would bring food and consume it together at their meetinghouse.

Understanding the differences between these two assemblages requires consideration of the local meanings with which foods may have been charged. Not surprisingly, given the long coastlines of the BVI, fish are noted to be plentiful (Colonial Office n.d.: 152/23\#78) and cheap (House of Commons 1790:285) at this time. In contrast, a contemporary merchant noted that "fresh meat is both dear and scarce through the whole island" (House of Commons 1790:285). Though some cattle were raised in the BVI, most were exported.

It is clear that only a few members of the Tortola meeting were wealthy, but the faunal evidence nonetheless suggests a choice by all members to present high-cost foods at gatherings. At first glance, this appears to run directly against the Quaker ideal of simplicity. The goal of simplicity was a rejection of pride, which could be occasioned through expressions of wealth or extravagance, and also of waste, in which some go hungry while others feast (Chenoweth 2006, 2011:51-53). Simplicity was expressed in "plain living": 
having no more than necessary but also having "integrity in all human relationships," including truth telling, fair business practices, and (at this time) a rejection of art and music (Tolles 1963:8-9). In the case of Tortola, presenting the most expensive foods (domestic meats) when some members were clearly far from wealthy and when adequate alternatives (fish) were available could easily be cast as prideful, wasteful, and extravagant.

But apart from these economic and religious considerations, class and racial value judgments were also at work. A key concept here is that of "idleness," which was integral to the construction of race in the Caribbean as well as Quakerism. One writer despaired of a group of free Africans on Tortola becoming "productive" members of society because their "inherent disposition to indulge in idleness, favoured by the facility of gaining a living by fishing and petty theft, rendered most of them incorrigible" (Wentworth 1835:220). While it is possible that whites who fished may not have been cast as being idle in precisely the same way, nonetheless the racist association of fishing, African peoples, and idleness in the minds of some raises the issue of broader negotiations of class and race.

Anne Yentsch (1994:152) notes that, unlike in Europe where hunting was a sport for the wealthy, in the New World domesticates gained higher status than hunted game or caught fish. Considering the abundance of fish and scarcity of domesticates discussed above, this association of domesticates with higher status and wild fish with lower might be suggested to run across the color line in the Caribbean. Domesticates, in addition to being more expensive, also required a measure of industry and diligence to produce. Ideas about fishing, idleness, blackness, and low status all seem tied up with each other, while domesticates, industry, whiteness, and higher status entailed each other as well.

It was in the context of these negotiations that BVI Quakerism was created and in which the practices of eating at the meetinghouse occurred. Idleness was also discussed in Quaker exegesis: "Idleness was looked upon with horror as the breeder of vice and vain conversation and Friends regarded diligence in a warrantable calling as a religious duty" (Tolles 1963:57; see also Walvin 1997:73-74). Thomas Chalkley, the first Quaker missionary to the BVI, is notably quoted by Tolles here as approving of these sentiments. Honest work was a counter to distractions, frivolities, and "vain conversation" that kept one from a simple life.

There are, then, two potential religious interpretations of the presentation of high-cost domesticates by members of the Tortola meeting when they gathered together: they might be seen as wasteful extravagances when a more economical food, wild-caught fish, was available, or they might be marks of industry and diligent effort on the part of the BVI planters, who produced them despite the ability to feed both their families and their idleness through fishing. Each of these is consistent with the Quaker value of simplicity, although in different ways, and in the case of the latter, this interpretation relies on local understandings that would not have been understood by Quakers in London or Philadelphia.

As noted above, BVI planters were committed to distinguishing themselves from enslaved people not just socially and economically but also religiously. Because the marginality of the BVI kept many planters materially little better off than the enslaved population, a performance of simplicity that entailed lowering material marks of status further might have been untenable to BVI whites. However, a religious differentiation that equated simplicity with industry, and the produce of that industry with economic status, could have served to perform and create Quaker-ness, planter-ness, whiteness, and status all at once. The archaeology indicates that this latter interpretation is the one that made sense to most members of the Tortola meeting. Daily practices of eating suggest the creation of a Quakerly ritualization of sacred diligence (and its material products, domesticates) and profane idleness. While echoes of these ideas are present in Quaker writings (cited above), their influence on practice here is altered by the context of Caribbean slavery.

\section{LARGE-SCALE PRACTICES AND QUAKER COMMUNITY}

At the outset of this article, I suggested that Quakerism cannot be defined by a list of practices - rather, it takes shape from practice. But how can a coherent community take shape from such divergent practices? Despite these variations and despite thousands of miles of distance, visions of a coherent Quaker community can still be found in the many letters that passed between Tortola and London's meetings in the 1740s and 1750s. Tortola greets London, "with the Salutation of true + tender Love, in the Bowels of our Lord and Savior Jesus Christ, and in his everlasting Covenant, we tenderly Salute you" (London Yearly Meeting n.d.a:3:100). London writes back that "the Blessed Work begun in your Island, [has] Excited in us a tender Concern for your Welfare, and fervent Desires for your Growth in the Love of the holy Truth" (London Yearly Meeting n.d.b:3:75). Despite distances, historian Frederick Tolles wrote, "Friends wherever they found themselves [felt] that they were all members of the same society" (1960:13). So the process of identification was effective despite variation in how ritualization occurred.

This evidence highlights what James Walvin (1997:46) has called the "fine web of literate contact" among Quakers: accounts of religious struggles were passed around as personal writings and printed tracts, and Quaker congregations often kept detailed records as part of a sense of their God-given "historic mission" in the world (Davies 2000:1). But as argued above, written works cannot be accepted as "real" versions of religion against which practices can be measured. Instead, I suggest that these writings are better seen as practices themselves, ones that can offer a window into the process of religious identity making that bridges the local nature of religion for both contemporaries and for present-day analysts. 
Walvin's written "web” is certainly part of what created the feelings of connection between Quakers in the BVI and elsewhere. Importantly, to remain consistent with the practice-centered view of identification and ritualization discussed above, this web should be seen as a web of practice and not a static set of documents: that is, actions of writing, distribution, and reading rather than static sources of rules by which members could live their lives. This perspective follows Giddens (1984:23), who points out that any effort to codify practice, such as the writing of laws (or here instructional epistles), must be seen as an "interpretation" in his meaning of that term, and its importance compared to more informal (and local) actions should not be overestimated.

Acts of writing and reading are single acts of practice among the many that are part of the negotiation of identity and process of ritualization, but they may also be seen as being larger in scope-impacting many more people's "contextuality of time-space" (Giddens 1984:3) — than many more ephemeral and momentary actions. As written works of Quaker exegesis are created and distributed, their content provides a background to local Quaker action that has more than the usual scope of single instances of refusing the "uncovering [of] the head, bowing, and bending the knee," et cetera (Gough 1789:76-77).

Following from the discussion of practice and identity earlier, we may examine Quakerism as a group of people engaged in drawing privileged distinctions in ways of acting (ritualization) based on a particular set of values or, to put it another way, through the understanding by members that their actions are differentiating the same "sacred" and the same "profane" as others seen to be Quakers. Following Bell and in keeping with the archaeology discussed above, these practices need not be identical. It is the intention to cite, in one's own practice, actions that are understood as "Quaker" that is more important than their precise replication. This understanding is in part worked out through this literary "web," wherein broad values and ways of drawing privileged distinctions - for instance, written interpretations of the value of simplicity - are described and shared. It is also in part worked out through the local, variable application of these ideas. It is the local-scale "seemingly trivial procedures followed in daily life" such as not bowing and hat wearing that Giddens suggests "have a more profound influence upon the generality of social conduct" (1984:22). Quakerism is therefore created at least as much in the variable minutia of individual performance as in widely shared documents: in the BVI, the realization of simplicity through expensive meat, for instance. Though, following Sahlins and de Certeau, these variations may lead to change in the broader group, those who make them are made no less a part of the process of ritualization as a result of this variation. Both large-scope and local interpretations are central parts of the creation of Quaker identity.

Seen in this way, written works provide a view into a less immediate but temporarily stabilized set of practices available to many people's "contextuality of time-space" for citation: they are well-known interpretations. This allows both the modern researcher and the contemporary attempting to enact connections between her or himself and a Quaker ideal to access one level of Quaker practice. Archaeology has here provided another, more local level: interpretations in the practices of daily life. Centrally, it is in moving between these two scales of analysis - the global and local, enduring written and transient material practices - that we can see into the unstable process of ritualization and the creation of a religious identity group.

\section{CONCLUSION}

Quakerism has long been associated more with the abolition movement than with slaveholding. Quakers are rightly famous for advocating an end to slavery and the slave trade, and they have done much to further causes of peace and equality for three centuries. However, what Quakerism "is" has been a subject of inquiry here. I suggested above that practice perspectives focus our attention on the minute scales of daily life (and the archaeologically accessible material objects they entail) and help us explore how they matter for large and influential social constructions like religion, race, and class. By studying the layout of the Little Jost Van Dyke site with a focus on practice, we are put in mind of the daily moments of its inhabitants' encounters: the long, hot walk between the Lettsoms' house and those of Rosett, Cudjoe, and their families. This form of separation is one recoverable only in the material culture these people left behind, but it is important to the interpretations of the version of Quakerism that took shape here. Though all Caribbean planters differentiated themselves from those they held enslaved, contrary written directives from outsider Quakers like Fox and Edmundson (long since deceased but whose work has been widely distributed and read by Quakers ever since) gave this differentiation added meaning on this site. The constructed landscape separated free and enslaved people, black and white, Quaker and non-Quaker, and this innovative ritualization of space adapted the idea of a Quaker community to the marginal Caribbean and to the continuation of slavery.

Quakerism is a religion of practice: one cannot be a Quaker without putting one's understanding of Quaker ideology into every action of daily life. Monthly meetings like Tortola's began, in part, as a way of morally policing each other's behavior. But this study suggests that each community may have enforced different ideas of this understanding. When they gathered at their meetinghouse, members were concerned with how they appeared to their fellows. The connections made in the BVI between different food sources and idleness or industry were unique to this context and not reflected in any written document, yet they appear as stark patterns in the archaeological record. Progressing from bones to acts of eating to ideas of industry and simplicity, we gain a picture of a Quakerism different from that expressed and created elsewhere. In these daily actions, highlighted by a consideration of practice, Quakerism comes to be. 
Though Quaker writings are full of directives on peace, it appears that even this basic tenet cannot be accepted without analysis. For the Lettsoms, peace and slavery could walk hand in hand. To modern eyes, this seems ironic and surprising, but in the marginal Caribbean amid an economy that was based on the appropriation of labor through the threat and accomplishment of violence, a wholesale adoption of Quakerism exactly as it was practiced in London might have been more surprising still. If identity is created in practice in local contexts, then any given group must form itself and negotiate space for itself amid other pressing local needs here, white-centered cooperation and differentiation from, as well as oppression of, enslaved Africans.

What emerged was a Quakerism connected to others in the Quaker world but adapted to the local context of the slavery-era Caribbean. These performances of religious identity do not directly follow from lists of traits, nor do letters from London encode a "real" static version of the religion from which BVI Quakers strayed. Both local practices and written exegesis are Giddens's "interpretations" (1984:23). The Quakerism of the BVI emerged from a negotiation between larger-scope, interpretative practices in written form and the minute practices of eating meat (or fish) and managing relationships with the enslaved Africans around them: that is, practices taken in local context, which were subject to all the local social and economic pressures of the BVI. The process of making Quakerism here is local and contextual but in conversation with and thus a part of a Quaker community that spread across the Atlantic world.

John M. Chenoweth Department of Behavioral Sciences, University of Michigan-Dearborn, Dearborn, MI 48128; jmchenow@ umich.edu

\section{NOTES}

Acknowledgments. My thanks go first to the people of the British Virgin Islands, whose history this is. This project was especially enabled by Mrs. Luce Hodge-Smith of the Department of Culture, Dr. Karl Dawson of H. Lavity Stoutt Community College, and the landowners, the Vanterpool family and Mr. Dwight Pickering. Major funding for this project was provided by the National Science Foundation under Doctoral Dissertation Improvement Grant No. 0929563. Any opinions, findings, and conclusions or recommendations expressed in this material are those of the author and do not necessarily reflect the views of the National Science Foundation. This project also received major funding from the British Virgin Islands Department of Culture, the American Philosophical Society's Lewis and Clark grant program, and UC Berkeley. I wish to thank Mark Hauser, editors Tom Boellstorff and Michael Chibnik, and the anonymous reviewers for their extensive and extremely helpful comments. Frederick H. Smith also provided comments on a related project that informed this article, and my UC Berkeley dissertation committee, Laurie Wilkie, Rosemary Joyce, Kent Lightfoot, and Ethan Shagan, all provided invaluable guidance throughout. Any errors that remain are, of course, entirely my own.

\section{REFERENCES CITED}

Aldenderfer, Mark

2012 Envisioning a Pragmatic Approach to the Archaeology of Religion. Archeological Papers of the American Anthropological Association 21:23-36.

Armstrong, Douglas V.

1990 The Old Village and the Great House: An Archaeological and Historical Examination of Drax Hall Plantation, St. Ann's Bay, Jamaica. Urbana: University of Illinois Press.

2003 Creole Transformation from Slavery to Freedom: Historical Archaeology of the East End Community, St. John, Virgin Islands. Gainesville: University Press of Florida.

Armstrong, Douglas V., and Kenneth G. Kelly

2000 Settlement Patterns and the Origins of African Jamaican Society: Seville Plantation, St. Ann's Bay, Jamaica. Ethnohistory 47(2):369-397.

Battle-Baptiste, Whitney

2011 Black Feminist Archaeology. Walnut Creek: Left Coast.

Bell, Catherine

1992 Ritual Theory, Ritual Practice. Oxford: Oxford University Press.

Bourdieu, Pierre

1977 Outline of a Theory of Practice. Cambridge: Cambridge University Press.

Bradley, Richard

2003 A Life Less Ordinary: The Ritualization of the Domestic Sphere in Later Prehistoric Europe. Cambridge Archaeological Journal 13(1):5-23.

Butler, Judith

1993 Bodies That Matter: The Discursive Limits of "Sex." New York: Routledge.

Cadbury, Henry J.

1936 Negro Membership in the Society of Friends. Journal of Negro History 21(2):151-213.

Camp, Stephanie M. H.

2004 Closer to Freedom: Enslaved Women and Everyday Resistance in the Plantation South. Chapel Hill: University of North Carolina Press.

Chenoweth, John M.

2006 "What'll Thou Have": Quakers and the Characterization of Tavern Sites in Colonial Philadelphia. Northeast Historical Archaeology 35(1):77-92.

2009 Social Identity, Material Culture, and the Archaeology of Religion: Quaker Practices in Context. Journal of Social Archaeology 9(3):319-340.

2011 Religion, Archaeology, and Social Relations: A Study of the Practice of Quakerism and Caribbean Slavery in the Eighteenth-Century British Virgin Islands. Unpublished Ph.D. dissertation, Department of Anthropology, University of California, Berkeley.

2012 Quakerism and the Lack of "Things" in the Early Modern. In Modern Materials: The Proceedings of CHAT Oxford, 2009. Studies in Contemporary and Historical Archaeology, 8. Brent 
Fortenberry and Laura McAtackney, eds. Pp. 73-84. Oxford: British Archaeological Reports.

In press The Archaeology of Quakerism in Philadelphia and Beyond: Identity, Context, and Conformity. In The Historical Archaeology of the Delaware Valley, 1600-1820. Richard Veit and David Orr, eds. Knoxville: University of Tennessee Press.

Clement, Christopher Ohm

1997 Settlement Patterning on the British Caribbean Island of Tobago. Historical Archaeology 31(2):93-106.

Colonial Office

N.d. Colonial Office Series of Documents. London: National Archives, Kew.

Craton, Michael

1997 Empire, Enslavement, and Freedom in the Caribbean. Princeton: Markus Wiener.

Dailey, Barbara Ritter

1991 The Early Quaker Mission and the Settlement of Meetings in Barbados. Journal of the Barbados Museum and Historical Society 39:24-46.

Davies, Adrian

2000 The Quakers in English Society, 1655-1725. Oxford: Clarendon.

de Certeau, Michel

1984 The Practice of Everyday Life. Steven F. Rendall, trans. Berkeley: University of California Press.

Delle, James A.

1998 An Archaeology of Social Space: Analyzing Coffee Plantations in Jamaica's Blue Mountains. Contributions to Global Historical Archaeology series. New York: Plenum.

1999 The Landscapes of Class Negotiation on Coffee Plantations in the Blue Mountains of Jamaica: 1790-1850. Historical Archaeology 33(1):136-158.

Dookhan, Isaac

1975 A History of the British Virgin Islands, 1672 to 1970. Epping,

UK: Caribbean Universities Press in association with Bowker. Dunn, Richard S.

1972 Sugar and Slaves: The Rise of the Planter Class in the English

West Indies, 1624-1713. Chapel Hill: University of North Carolina Press.

Durham, Harriet Frorer

1972 Caribbean Quakers. Hollywood: Dukane.

Farnsworth, Paul

1999 From the Past to the Present: An Exploration of the Formation of African-Bahamian Identity during Enslavement. In African Sites Archaeology in the Caribbean. Jay B. Haviser, ed. Pp. 94 130. Princeton: Marcus Wiener.

Ferguson, Leland

2011 God's Fields: Landscape, Religion, and Race in Moravian Wachovia. Gainesville: University Press of Florida.

Fox, George

1701 Gospel Family-Order Being a Short Discurse [sic] Concerning the Ordering of Families, Both of Whites, Blacks and Indians. Philadelphia: Reinier Jansen.

1952 The Journal of George Fox. Cambridge: Cambridge University Press.

Frost, J. William

2003 From Plainness to Simplicity: Changing Quaker Ideals for
Material Culture. In Quaker Aesthetics. Emma Jones Lapsansky and Anne Verplanck, eds. Pp. 16-40. Philadelphia: University of Pennsylvania Press.

Giddens, Anthony

1984 The Constitution of Society. Berkeley: University of California Press.

Gough, John

1789 A History of the People Called Quakers: From Their First Rise to the Present Time. Dublin: R. Jackson.

Gragg, Larry Dale

2009 The Quaker Community on Barbados: Challenging the Culture of the Planter Class. Columbia: University of Missouri Press.

Handler, Jerome S.

2002 Plantation Slave Settlements in Barbados, 1650s to 1834. In In the Shadow of the Plantation: Caribbean History and Legacy. Alvin O. Thompson, ed. Pp. 123-161. Kingston: Ian Randle.

Handler, Jerome S., and Frederick Lange

1978 Plantation Slavery in Barbados: An Archaeological and Historical Investigation. Cambridge, MA: Harvard University Press.

Harrigan, Norwell, and Pearl Varlack

1975 The Virgin Islands Story. Kingston: Caribbean Universities Press.

Hauser, Mark

2008 The Archaeology of Black Markets: Local Ceramics and Economies in Eighteenth-Century Jamaica. Florida Museum of Natural History: Ripley P. Bullen series. Gainesville: University Press of Florida.

2011 Routes and Roots of Empire: Pots, Power, and Slavery in the 18th-Century British Caribbean. American Anthropologist 113(3):431-447.

Hawkes, Christopher

1954 Archaeological Theory and Method: Some Suggestions from the Old World. American Anthropologist 56(2):155168 .

Hicks, Dan

2007 "The Garden of the World": An Historical Archaeology of Sugar Landscapes in the Eastern Caribbean. Volume 1632. Oxford: British Archaeological Reports.

Higman, Barry

1998 Montpelier, Jamaica: A Plantation Community in Slavery and Freedom, 1739-1912. Kingston: University of the West Indies Press.

Hodge, Christina J.

2005 Faith and Practice at an Early-Eighteenth-Century Wampanoag Burial Ground: The Waldo Farm Site in Dartmouth, Massachusetts. Historical Archaeology 39(4): 73-94.

House of Commons

1790 Minutes of Evidence Taken Before a Committee of the House of Commons . . . to Consider Further of the Circumstances of the Slave Trade. London: House of Commons, Parliament of Great Britain.

Jenkins, Charles Francis

1923 Tortola: A Quaker Experiment of Long Ago in the Tropics. London: Friends' Bookshop. 
Joseph, J. W.

1993 White Columns and Black Hands: Class and Classification in the Plantation Ideology of the Georgia and South Carolina Lowcountry. Historical Archaeology 27(3):57-73.

Joyce, Rosemary A.

2012 What Should an Archaeology of Religion Look Like to a Blind Archaeologist? Archaeological Papers of the American Anthropological Association 21:180-188.

Keane, Webb

2008 The Evidence of the Senses and the Materiality of Religion. Journal of the Royal Anthropological Institute 14(s1):S110 S127.

Kelly, Kenneth G.

2008 Creole Cultures of the Caribbean: Historical Archaeology in the French West Indies. International Journal of Historical Archaeology 12(4):388-402.

Kent, Michael

2009 Defence Development in the British Virgin Islands, 1530 1815. Unpublished Ph.D. dissertation, Department of Archaeology, University of Bristol, UK.

Lettsom, John Coakley

2003[1804] Recollections or Reminiscences. In Sambrook Court: The Letters of J. C. Lettsom at the Medical Society of London. C. Lawrence and F.A. Macdonald, eds. Pp. 12-25. London: Wellcome Trust Center for the History of Medicine at University College London.

London Yearly Meeting

N.d.a Epistles Received, Manuscript. London: Friends House Library.

N.d.b Epistles Sent, Manuscript. London: Friends House Library.

Mahoney, Shannon S., Autumn Barrett, Mark Kostro, and Michael L. Blakey

2005 Analysis of Human Remains from Guana Island, BVI. Report No. 4. Williamsburg: Institute for Historical Biology, Department of Anthropology, College of William and Mary.

McDaniel, Donna, and Vanessa Julye

2009 Fit for Freedom, Not for Friendship: Quakers, African Americans, and the Myth of Racial Justice. Philadelphia: QuakerPress.

O’Neal, Michael E.

2012 Slavery, Smallholding, and Tourism: Social Transformations in the British Virgin Islands. New Orleans: Quid Pro.

Orser, Charles E.

1988 Toward a Theory of Power for Historical Archaeology: Plantations and Space. In The Recovery of Meaning: Historical Archaeology in the Eastern United States. Mark P. Leone and Parker B. Potter, eds. Pp. 313-344. Washington, DC: Smithsonian Insitution Press.

2007 The Archaeology of Race and Racialization in Historic America. American Experience in Archaeological Perspective series. Gainesville: University Press of Florida.

Ortner, Sherry B.

1984 Theory in Anthropology since the Sixties. Comparative Studies in Society and History 26(1):126-166.
Otto, John

1984 Cannon's Point Plantation, 1794-1860: Living Conditions and Status Patterns in the Old South. Studies in Historical Archaeology series. New York: Academic.

Pauketat, Timothy R.

2001 Practice and History in Archaeology: An Emerging Paradigm. Anthropological Theory 1(1):73-98.

Sahlins, Marshall

1981 Historical Metaphors and Mythical Realities: Structure in the Early History of the Sandwich Islands Kingdom. Ann Arbor: University of Michigan Press.

Schatzki, Theodore R.

2001 Introduction: Practice Theory. In The Practice Turn in Contemporary Theory. Theodore R. Schatzki, Karin Knorr Cetina, and Eike von Savigny, eds. Pp. 1-14. New York: Routledge.

Silliman, Stephen W.

2009 Change and Continuity, Practice and Memory: Native American Persistence in Colonial New England. American Antiquity 74(2):211-230

Singleton, Theresa A

2001 Slavery and Spatial Dialectics on Cuban Coffee Plantations. World Archaeology 33(1):98-114.

Soderlund, Jean R.

1985 Quakers and Slavery: A Divided Spirit. Princeton: Princeton University Press.

Stahl, Ann B.

2008 Dogs, Pythons, Pots, and Beads: The Dynamics of Shrines and Sacrificial Practices in Banda, Ghana, 1400-1900 C.E. In Memory Work: Archaeologies of Material Practices. Barbara J. Mills and William H. Walker, eds. Pp. 159-186. Santa Fe: School of Advanced Research.

Tolles, Frederick B.

1960 Quakers and the Atlantic Culture. New York: Macmillan. 1963[1948] Meeting House and Counting House: The Quaker Merchants of Colonial Philadelphia, 1682-1763. New York: W. W. Norton.

Walvin, James

1997 The Quakers: Money and Morals. London: John Murry.

Wentworth, Trelawney

1835 The West India Sketch Book. London: Whittaker.

Wilkie, Laurie A.

2000 Creating Freedom: Material Culture and African American Identity at Oakley Plantation, Louisiana, 1840-1950. Baton

Rouge: Louisiana State University Press.

Wilkie, Laurie A., and Paul Farnsworth

2005 Sampling Many Pots: An Archaeology of Memory and Tradition at a Bahamian Plantation. Gainesville: University Press of Florida.

Yentsch, Anne Elizabeth

1994 A Chesapeake Family and Their Slaves: A Study in Historical Archaeology. Cambridge: Cambridge University Press.

Young, Amy L.

1999 Archaeological Investigations of Slave Housing at Saragossa Plantation, Natchez, Mississippi. Southeastern Archaeology 18(1):57-68. 